\title{
Article
}

\section{The P7 approach to the Olympic challenge: Sharing a practical framework for mission preparation and execution}

\author{
Collins, D., and Cruickshank, A.
}

Available at http://clok.uclan.ac.uk/12242/

Collins, D., ORCID: 0000-0002-7601-0454 and Cruickshank, A. ORCID: 00000002-8893-2341 (2015) The P7 approach to the Olympic challenge: Sharing a practical framework for mission preparation and execution. International Journal of Sport and Exercise Psychology, 13 (1). pp. 21-28. ISSN 1557-251X

It is advisable to refer to the publisher's version if you intend to cite from the work. http://dx.doi.org/10.1080/1612197X.2014.982677

For more information about UCLan's research in this area go to http://www.uclan.ac.uk/researchgroups/ and search for <name of research Group>.

For information about Research generally at UCLan please go to http://www.uclan.ac.uk/research/

All outputs in CLoK are protected by Intellectual Property Rights law, including Copyright law. Copyright, IPR and Moral Rights for the works on this site are retained by the individual authors and/or other copyright owners. Terms and conditions for use of this material are defined in the policies page.

\section{CLoK}

Central Lancashire online Knowledge www.clok.uclan.ac.uk

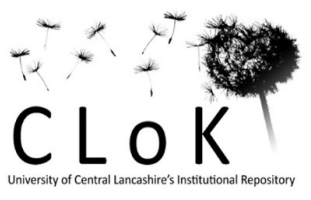


This is an Accepted Manuscript of an article published by Taylor \& Francis in International Journal of Sport and Exercise Psychology in January 2015, available online:

http://www.tandfonline.com/doi/abs/10.1080/1612197X.2014.982677\#.VbEgB03bLcs

PLEASE REFER TO THE PUBLISHED VERSION FOR CITING PURPOSES

Submitted for Special Issue: "Preparing Athletes for the Olympic Games"

The $\mathbf{P}^{7}$ approach to the Olympic challenge: Sharing a practical framework for mission preparation and execution

Dave Collins* \& Andrew Cruickshank

Institute of Coaching and Performance, University of Central Lancashire

*Correspondence concerning this article should be addressed to Dave Collins, Institute of Coaching and Performance, University of Central Lancashire, Preston, PR1 2HE. Email: DJCollins@uclan.ac.uk, Dave@gm4p.com 


\begin{abstract}
The Olympic Games represent the biggest and third biggest sporting occasions in the world (Summer and Winter respectively). As such, dealing with the various challenges and optimizing performance at this event has been an important dual focus for team leaders, coaches, performers, and their supporting sport psychologists. In this paper, we share an organizational approach to planning and preparation that, in our experience, provides an effective setup for athletes, coaches, and support teams alike. Specifically, this presented framework enables the focused tasking of support staff and resources to address both individual and specific challenges. To illuminate the route via which this approach delivers its impact, underpinning mechanisms, advantages, and other considerations are also presented.
\end{abstract}

Keywords: Olympics; organization; planning; preparation; support team 


\section{Collins and Cruickshank}

\section{The $\mathbf{P}^{7}$ approach to the Olympic challenge: Sharing a practical framework for mission preparation and execution}

The Olympic Games represent the biggest and third biggest sporting occasions in the world (Summer and Winter respectively). The combination of media attention, village life, the multisport environment, and coping with the wait (especially while others have finished and entered "party mode") makes for a potent challenge to even the most experienced of athletes (Arnold \& Sarkar, 2014). This challenge also permeates to all members of the support staff, including sport psychologists (Harberl \& Peterson, 2006; Sharp, Hodge, \& Danish, 2014). As such, helping individuals to develop and then follow well-considered plans is one of the most important components of success. Indeed, structured and detailed planning can work to remove roadblocks before they occur and provide crucial reassurance and confidence to all involved (including external groups as well; e.g., the media: Cruickshank, Collins, \& Minten, 2014).

Given that specific psychology-focused preparation programs have been previously presented in the literature (e.g., Blumenstein \& Lidor, 2008; Gordin \& Henschen, 2012), it is clear that well-designed and well-developed approaches of this kind have a part to play in advancing support provision and performance. In a more general sense, and as an essential precursor to "capital P" psychology interventions (i.e., those which address specific and specified mental issues), there are, however, some simpler and more fundamental things which can be done. Accordingly, we suggest that overt attention to all aspects of preparation and execution can bring benefits to the psychological wellbeing of performers and, in addition, the broader performance team. In short, anything that reassures performers that all aspects are organized and allowed for (thereby optimizing confidence and minimizing worry) will have an arguably minor but often significant psychological impact. 
Specifically, the approach that we outline, which has evolved over 20 World, European, and Olympic competitions, extends beyond coach leadership alone (cf. Din \& Paskevich, 2013) and toward a more holistic preparation process that can allocate responsibility to and empower all parts of the support team. While the principles of this approach are not novel, we hope that their packaging may offer a useful contrast or addition to the tools already used by established sport psychologists, as well as something which less experienced practitioners may more directly adopt as they head into an Olympics or other major event. Certainly, our work across a number of such competitions suggest that, even in the apparently ever-more sophisticated performance environment, common sense issues are still "banana skins" for many performers, support practitioners, and team managers alike. Accordingly, and following the experience-based contributions of others (e.g., Harberl \& Peterson, 2006; Haberl \& McCann, 2012; Hodge \& Hermansson, 2007; Samulski \& Lopes, 2008; Galloway, 2007; Portenga, Aoyagi, \& Statler, 2012; Vernacchia \& Henschen, 2008), we therefore take a reflective rather than investigative approach to share a framework that, for us, has helped to manage the Olympic challenge.

\section{The planning framework and its basis}

Research shows that a wide variety of administration-based challenges can act to initiate or in themselves cause derailment of the Olympic preparation process through distraction, loss of confidence, or direct hampering of performance-focused efforts (for a full review see Gould \& Maynard, 2009). Accordingly, and matching the almost military-scale challenges apparent at such a major sporting event (for this comparison, see Goodhart \& Chataway, 1968), we turn to the first author's earlier experiences in combat settings. More specifically, we consider the military-based mantra of anticipating, preparing for, and countering potential problems through "Plan A" and "Plan B" strategies before contact (Pathiravithana, 2014). By definition, such an approach requires ongoing testing and 


\section{Collins and Cruickshank}

refinement in pressurized circumstances, with plans based on substantial experience and carefully considered adjustments. Supporting its transfer to other fields, this style of identifying and planning for possible obstacles and setbacks is now also finding its way into mainstream applications (e.g., in business; Sabre, 2014).

Reflecting the importance of preparing for potential issues, "Perfect Prior Preparation Prevents $\mathrm{P}^{* * *}$ Poor Performance" (hereafter $\mathrm{P}^{7}$ ) is a call that is taught from the earliest moments in military training. In this manner, checking that preparation has been as comprehensive as possible is a feature of standard methods such as combat appreciations, where a military planner is required to plot a base/ideal strategy while simultaneously addressing as many possible variations of what might go wrong (Pathiravithana, 2014). Notably, such attention to potential issues is something that has been generally overlooked within sport psychology literature but has been implicated in recent accounts of best practice within an Olympic Games context. Specifically, and in contrast to McCann's (2008) view that "sport psychology success is not preventing problems or challenges ... . [but] helping athletes and coaches prevent the problems from 'going critical'”' (p. 275), Arnold and Sarkar's (2014) work with 15 leading practitioners pointed to the importance of preventative strategies. For example, one participant in this study reported:

We had some real life stressors, where the schedule [of competition at the Olympics] changed literally the day before play started. We were all going to go to the opening ceremony, then suddenly three out of the four [athletes] couldn't go as they were playing the next day. Their opponents changed as well to the top seeds in their group, which was a big change in perspective. So this really did throw us a little bit, but it was an "unexpected" that we had prepared for pre-Games. (Arnold \& Sarkar, p. 6) 
Based on this and other perceptions, Arnold and Sarkar concluded that practitioners need to have techniques in place that enable individuals to proactively prevent and manage the various potential demands of Olympic participation.

Our example of such an approach, as applied by the first author and colleagues for track and field athletes at the Beijing Olympics in 2008, is shown in Figure 1. The presented structure requires each respondent to consider the possible challenges of the impending contest against a chronological design which denotes when, where, and what stage of preparation core supporting activities/processes should be engaged (as detailed in the columns on the left hand side of the figure). Please note that, while the respondents in this instance are athletes, different versions can be used for support staff. Notable features include proactive strategies to counter issues, developing a confidence that your preparation is extensive and sound, and acknowledging things that might go wrong while ensuring that there are resources available to counter them ${ }^{1}$ (Harberl \& Peterson, 2006). Of course, this consideration of what might go wrong needs to be done well in advance of competition to then allow focus to return to wholly positive and productive behaviors in the immediate period before performance.

It should also be emphasized that Figure 1 represents a template for the entire team. Indeed, each athlete or support staff member builds on this basis by adding details of their own event schedule plus associated challenges, individual concerns and developed solutions, and additional "wrinkles" and strategies that they have evolved through competitive experience. Additionally, the refinement of such plans represent a collaboration between a range of relevant parties; in the case of the athlete, for example, inputs will be sourced from their coach(es), Performance Manager (hereafter PM), and other lead support staff (e.g.,

\footnotetext{
${ }^{1}$ Given the level of required detail, the figure contains a lot of information with 'shorthand' used for parsimony. For example, in Phase 2 the athlete is reminded to avoid locally purchased medication with reference to Alain Baxter, a UK skier who lost his bronze medal at the Salt Lake City Games in 2002 after testing positive for a banned substance that originated from a US nasal spray which differed in recipe from its UK equivalent.
} 


\section{Collins and Cruickshank}

physiotherapist, psychologist). Illuminating another important benefit that use of the presented framework may bring, this open discussion can also facilitate group-wide involvement, buy in, and commitment; all crucial features of developing the respondent's self-efficacy for the forthcoming event (Bandura, 1977). In addition, any residual or specialist concerns are highlighted, enabling the PM to source and deploy further specialist support to address these issues. In short, we have found that the process of such planning makes almost as big a contribution as addressing the features it highlights.

\section{How the planning framework works}

Clearly, focusing on what to do rather than what will happen if I... is a simple but sometimes hard to achieve guideline. As such, the $\mathrm{P}^{7}$ approach has worked in our experience, if by no other means, through establishing and maintaining a focus on the process of performance preparation rather than the tempting, often media-induced, and well known emphasis on outcome (cf. Harberl \& Peterson, 2006; Hermansson \& Hodge, 2012). Importantly, and to prevent any stifling of adaptability or improvisation, the framework can be deployed as a "check and balance" tool or as a more tightly followed procedure. Indeed, while many athletes and support staff will have a clear understanding of what is required of them at different moments (but who still benefit from external audit and confirmation), there are also many who will overlook some basics as they move into the "white heat" of competition and negotiate a highly distracting village. As ever, careful consideration of each individual's needs and preferences should determine application; in this case, balancing the framework's use as a reminder and more rigid guide.

From a mechanistic angle, the framework further addresses several previously identified sources of stress, including travel, food, boredom (cf. Gould \& Maynard, 2009), staff, drug testing (cf. Vernacchia \& Henschen, 2008), media (Harberl \& Peterson, 2006; Kristiansen, Hanstad, \& Roberts, 2011), and the quality and perceived quality of preparation 
(Olusoga, Maynard, Hays, \& Butt, 2012). Epistemologically, such an approach has its roots in the classic Antecedents-Behavior-Consequences model of cognitive-behavioral approaches to performance optimization; whereby individuals increasingly engage in specific behaviors when these are promoted by antecedent stimuli and systematically reinforced by controlled consequences (Martin \& Pear, 2003). Indeed, the framework works to set the conditions for individuals to engage with fundamental preparatory behaviors (by providing a reminder/guide of the activities required at particular moments) and systematically reinforces these behaviors through the individual's consequent feelings of control and confidence (as further supported by all others who have collaborated on this plan and see it being executed). Highlighting its potential for multi-level impact, comfort and confidence may also be promoted in the group surrounding the specific individual as they deliver on their plans; something which may, for example, help to reduce stress in a support staff that also has a significant stake in an athlete's performance (cf. Arnold \& Sarkar, 2014).

As well as this core foundation, the presented framework is more specifically grounded in the adaptation work of Fiske (2004; also see Schinke, Battochio, Dubuc, Apolloni, \& Tenenbaum, 2008). Indeed, through the early identification of, and structured solution for, the individual's perceived challenges, the development and maintenance of optimized emotions is promoted (cf. Pensgaard \& Duda, 2003). Finally, by anticipating and establishing plans and contingencies, this approach is also designed to avoid the inherent challenges (and potential mistakes) of thinking under pressure to solve unexpected issues (Pensgaard, 2008). Of course, these will almost always occur to some extent. However, just as with the military traditions that spawned the $\mathrm{P}^{7}$ approach, rigorous and open debriefs on such "unexpecteds" have, in our experience, often shown that they clearly could and should have been anticipated and planned for. 


\section{Collins and Cruickshank}

Significantly, the approach that we have presented and advocated in this paper has worked well across a variety of high-level competitions, including world and junior events. Certainly, the nature of challenge faced by younger athletes is largely no different to those operating at senior level (cf. Kristiansen \& Roberts, 2010) and an early sensitization and treatment of the various organizational challenges would seem a logical part of their performance "finishing school". With regard to the increasing number of individuals who may be concerned (or consider themselves concerned) with a performer's preparation (Collins, Trower, \& Cruickshank, 2012), the $\mathrm{P}^{7}$ approach also helps to keep everyone focused appropriately on the same page. Such common communication and shared mental models (Cannon-Bowers, Salas, \& Converse, 1990; Mascarenhas \& Smith, 2011) are crucial in the pressured environment of a major event, whether solely between sport psychologists (Portenga et al., 2012) or the wider support team (Collins \& Collins, 2011; Sharp et al., 2014).

\section{Concluding comments}

In our experience of applying the approach presented within this paper, all who have completed it feel more capable and confident in their capacity to meet the significant challenges of performance at a major event, including knowing that help is always available and precisely where from (cf. Williams \& Andersen, 2012). Indeed, reflecting the excellent “cross boundary" approach of Williams and Andersen (2012: although this is not necessarily our epistemological stance), the perspective we have shared here emphasizes and structures the essential "all in it together-ness" that invariably characterizes successful performance. Importantly, while our perceptions are locked to our work in British sport, the individualized nature of the presented framework and common role of support teams suggests that this may hold some potential for cross-cultural application. We consequently commend the use of this 
tool, either by or through the psychologist in collaboration with other support practitioners, but certainly for application across both the performance and support team environment.

Acknowledgements: The first author gratefully acknowledges the contributions made by world class administrators David Dix and Simon Nathan to the evolution of these ideas. 
Figure 1. Exemplar Olympic Games preparation strategy template (as used for the Beijing Olympics, 2008)

PHASE 1: Travel and Acclimatization (INSERT FLIGHT TIMES AND DURATION)

Coach: [name]

Athlete: [name]

Performance Manager: [name]

Event(s): [name]

Designated Coach: [name]

\begin{tabular}{|c|c|c|c|c|c|}
\hline & & PHYSIOLOGICAL ${ }^{2}$ & MENTAL/ORGANIZATIONAL & TECHNICAL/TACTICAL & PHYSICAL/MEDICAL \\
\hline \multirow{5}{*}{ 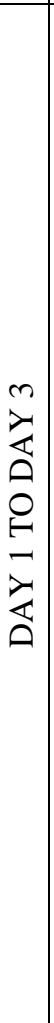 } & \multirow{5}{*}{ 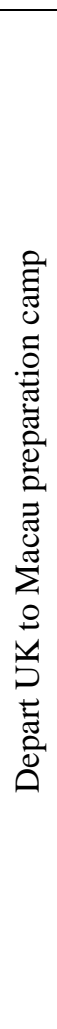 } & $\begin{array}{l}\text { Hydration Strategy: } \\
\text { - } \quad \text { See nutritionist early to plan strategy } \\
\text { - } \quad \text { Purchase fluid for plane after check in } \\
\quad \text { Notration strategy pre, in and after flight }\end{array}$ & $\begin{array}{l}\text { Mental Preparation Plan: } \\
\text { Distraction techniques (e.g. good book, DVD, } \\
\text { cards) } \\
\text { - Time slipping towards Macau in advance - } \\
\text { check with PM for data from practice trips } \\
\text { - Expect and prepare for 'last minute' media } \\
\text { attention }\end{array}$ & $\begin{array}{l}\text { Technical Plan: } \\
\text { - } \quad \text { What do I need to do to qualify? } \\
\text { Climatic influences on planning }\end{array}$ & $\begin{array}{l}\text { Training } \\
\quad \quad \text { Training loads before departure } \\
\quad \quad \text { Training schedule for Macau } \\
\quad \text { Timing of training sessions } \\
\\
\text { (Consider and act on NGB guidelines) }\end{array}$ \\
\hline & & $\begin{array}{l}\text { Nutrition Strategy: } \\
\text { - } \quad \text { Book appropriate flight meals } \\
\text { - } \quad \text { Aving snacks for flight? } \\
\quad \text { tea/coffee/alcohol }\end{array}$ & 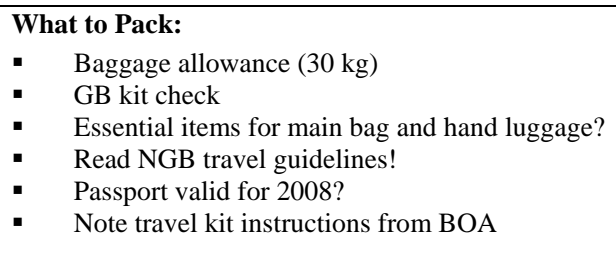 & $\begin{array}{l}\text { Tactical: } \\
\text { The challenge of the Beijing } \\
\text { timetable! } \\
\text { Details of potential opponents } \\
\text { taken to facilitate planning and } \\
\text { consideration } \\
\text { What to say publicly about } \\
\text { tactical plan }\end{array}$ & $\begin{array}{l}\text { Medical Plan in UK: } \\
\text { - } \quad \text { Complete NGB medical form } \\
\text { - } \quad \text { Dental Check } \\
\quad \text { Drugs requirement for TUE / } \\
\quad \text { Update Anti-Doping Whereabouts }\end{array}$ \\
\hline & & $\begin{array}{l}\text { Travel and Acclimatisation: } \\
\text { - } \quad \text { Follow previously developed sleep plan } \\
\quad \text { NGB aim is for } 2-3 \text { days acclimatization } \\
\quad \text { process } \\
\text { - } \quad \text { Use data from previous trips to confirm }\end{array}$ & $\begin{array}{l}\text { Personal Coach: } \\
\quad \quad \text { Limited accreditations in Beijing } \\
\quad \text { Estimated cost for PC to attend } £ 2.5-£ 3 \mathrm{k} \\
\quad \text { Check chances of access with PM }\end{array}$ & $\begin{array}{l}\text { Training Load: } \\
\text { Danger of over training } \\
\text { What is the aim of your training } \\
\text { in the tapering phase? }\end{array}$ & $\begin{array}{l}\text { Vaccinations Summary } \\
\quad \text { Read NGB guidelines } \\
\quad \text { Action - see NGB doctor } \\
\quad \text { PM to check with central medical } \\
\text { database }\end{array}$ \\
\hline & & $\begin{array}{l}\text { Recovery from Travel: } \\
\text { - } \quad \text { Walk around hotel and local area on arrival to } \\
\text { get your bearings } \\
\text { - Sleep late with curtains closed for first few } \\
\text { days } \\
\text { - Breakfast delivered late to room }\end{array}$ & $\begin{array}{l}\text { Currency: } \\
\text { INSERT EXCHANGE RATES } \\
\text { - } \quad \text { Hong Kong (HK\$) can be used in Macau } \\
\text { - } \quad \text { China (Yuan or CNY) in Beijing }\end{array}$ & $\begin{array}{ll}\text { Training Details: } \\
\text { - } & \text { Consider issued plans and } \\
& \text { schedules for training } \\
\text { - } & \text { Use of Macau track, running } \\
\text { trails, golf course run and twin } \\
\quad \text { weights facilities }\end{array}$ & $\begin{array}{l}\text { Medical Plan for Far East: } \\
\text { - } \quad \text { Physiotherapy } \\
\text { - } \quad \text { Massage } \\
\text { - } \quad \text { Ice Baths }\end{array}$ \\
\hline & & $\begin{array}{l}\text { Weather Reports: } \\
\text { - www.smg.gov.mo } \\
\text { - } \quad \text { Liaise with members from last year's world } \\
\text { team for details of venue, weather, etc. }\end{array}$ & $\begin{array}{l}\text { Sharing a room with a team mate (unavoidable!): } \\
\text { - } \quad \text { Simple rules of sharing } \\
\text { - } \quad \text { Healthy living } \\
\text { Use hand gel regularly }\end{array}$ & & $\begin{array}{l}\text { Medical Team: } \\
\text { - } \quad \text { Drs. XXX and YYY } \\
\text { - } \quad \text { Physios ZZZ, AAA, BBB \& CCC } \\
\text { - } \quad \text { Soft tissue therapist WWW }\end{array}$ \\
\hline
\end{tabular}

"Long journeys cause tiredness and fatigue even without changes in the time zone. Simple strategies, preparation and being well organized may help reduce this and enhance your performance on arrival."

${ }^{2}$ Develop this section with athlete/staff member through reference to NGB guidelines 
PHASE 2: Macau Preparation Camp (INSERT STANDARD AVAILABLE TRAINING TIMES)

\begin{tabular}{|c|c|c|c|c|c|}
\hline & & PHYSIOLOGICAL & MENTAL/ORGANIZATIONAL & TECHNICAL/TACTICAL & PHYSICAL/MEDICAL \\
\hline \multirow{5}{*}{ 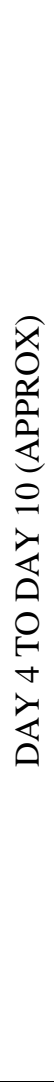 } & \multirow{5}{*}{  } & $\begin{array}{l}\text { Hydration Strategy: } \\
\text { - } \quad \text { NGB will provide Powerade / bottled water } \\
\text { - } \quad \text { Discuss with NGB performance and } \\
\text { medical teams. }\end{array}$ & $\begin{array}{l}\text { Refinement of Mental Preparation: } \\
\text { - } \quad \text { Practicing for day of competition } \\
\text { - } \quad \text { Running through plan B's } \\
\quad \text { Counteracting boredom }\end{array}$ & $\begin{array}{l}\text { Technical Plan: } \\
\text { - } \quad \text { Preparing for IAAF Competition } \\
\text { Rules } \\
\text { - Personal, specialist event and } \\
\text { other coach input? }\end{array}$ & $\begin{array}{l}\text { Monitoring your Travel Adaptation: } \\
\text { - } \quad \text { Complete daily your am/pm urine } \\
\text { assessments } \\
\text { - } \quad \text { AM body weight pre breakfast } \\
\text { - } \quad \begin{array}{l}\text { Complete daily brief jet lag } \\
\text { - questionnaire } \\
\text { - }\end{array} \\
\begin{array}{l}\text { Review daily feedback and modify } \\
\text { training / fluids }\end{array} \\
\end{array}$ \\
\hline & & $\begin{array}{l}\text { Nutrition Strategy: } \\
\text { - Maintaining or adapting normal diet to } \\
\text { - } \quad \text { Deet Far East conditions } \\
\text { - } \quad \text { Confirming Nutritional Pack for } \\
\quad \text { competition on day? }\end{array}$ & $\begin{array}{l}\text { Distraction Plans to be employed: } \\
\text { - } \quad \text { Recreational \& leisure activities } \\
\text { - } \quad \text { www.macautourism.gov.mo } \\
\text { - } \quad \text { Group and individual mentality } \\
\text { - } \quad \text { Trips to town }\end{array}$ & $\begin{array}{l}\text { Training Plan: } \\
\text { Tapering } \\
\text { "Competing" at pre-set } \\
\text { competition time } \\
\text { Confirm or adapt warm up } \\
\text { (timing and content) }\end{array}$ & $\begin{array}{l}\text { Medical Plan for Macau: } \\
\quad \text { Physiotherapy? } \\
\quad \text { Massage? } \\
\quad \text { Regeneration sessions? }\end{array}$ \\
\hline & & $\begin{array}{l}\text { Essential Behavior } \\
\text { - Carry and drink bottle fluid } \\
\text { Caution with uncooked food, cold food and } \\
\text { salads }\end{array}$ & $\begin{array}{l}\text { Team Meetings: } \\
-\quad \text { Insert expected schedule } \\
\text { Media } \\
\bullet \quad \text { Insert expected schedule }\end{array}$ & $\begin{array}{l}\text { Tests: } \\
\text { - Formal or Informal? (decide your } \\
\text { taper test) }\end{array}$ & $\begin{array}{l}\text { Medical - General Health } \\
\quad \text { Insect repellent / cream } \\
\quad \text { Gear appropriate clothes at dusk! } \\
\quad \text { precautions - wash / gen hands } \\
\quad \text { regularly! } \\
\quad \text { Carry personal hand gel } \\
\end{array}$ \\
\hline & & 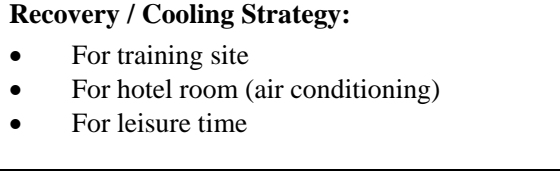 & $\begin{array}{l}\text { Communication Plan for Significant Others!! } \\
\text { - Keeping in touch with personal coach } \\
\text { - Keeping in touch with family / friends in the } \\
\quad \text { UK }\end{array}$ & $\begin{array}{l}\text { Review: } \\
\text { - ..of prep camp with personal or } \\
\quad \text { team coach }\end{array}$ & $\begin{array}{l}\text { Anti-Doping } \\
\text { - } \quad \text { At least one visit likely } \\
\text { - Note that IN competition rules } \\
\text { apply from opening of Village so } \\
\text { almost all affected }\end{array}$ \\
\hline & & $\begin{array}{ll}\text { Environmental: } \\
\text { - } & \text { Sunburn } \\
\text { - } & \text { Humidity } \\
\text { Exhaustion } & \text { Pollution } \\
\end{array}$ & $\begin{array}{ll}\text { Preparing for Beijing } \\
\text { - } & \text { Washing kit } \\
\text { - } & \text { Packing bags for departure } \\
\text { - } & \text { Competition kit check }\end{array}$ & $\begin{array}{l}\text { Media } \\
\text { - Aware of media visits to training } \\
\text { on two scheduled days }\end{array}$ & $\begin{array}{l}\text { NO LOCALLY PURCHASED } \\
\text { MEDICATION!! } \\
\text { Remember Alain Baxter!! }\end{array}$ \\
\hline
\end{tabular}


PHASE 3: Departure for Beijing (INSERT FLIGHT TIMES AND DURATION)

\begin{tabular}{|c|c|c|c|c|}
\hline & PHYSIOLOGICAL & MENTAL/ORGANIZATIONAL & TECHNICAL/TACTICAL & PHYSICAL/MEDICAL \\
\hline 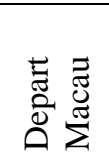 & $\begin{array}{ll} & \text { Hydration Strategy } \\
- & \text { Nutrition Strategy }\end{array}$ & $\begin{array}{l}\text { - } \quad \text { Packing and baggage drop off times } \\
\text { - } \\
\text { - }\end{array}$ & Training on departure day? & - Individual medical support plan \\
\hline
\end{tabular}

PHASE 4: Arrival in Beijing (INCLUDE STANDARD ‘SITE RECCE’ PROCEDURE)

\begin{tabular}{|c|c|c|c|c|}
\hline & PHYSIOLOGICAL & MENTAL/ORGANIZATIONAL & TECHNICAL/TACTICAL & PHYSICAL/MEDICAL \\
\hline \multirow{3}{*}{ 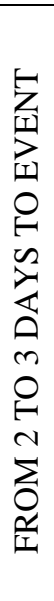 } & $\begin{array}{l}\text { 'First Shock' Strategy } \\
\text { - Hydration on landing and STAY COOL!! } \\
\text { - } \quad \text { Potential wait for visa check, even with Olympic } \\
\text { - } \quad \text { lanes } \\
\text { Bag carrying is covered - let them/us do it! }\end{array}$ & $\begin{array}{ll} & \text { Village Familiarisation } \\
- & \text { Olympic atmosphere } \\
- & \text { Visit Stadium } \\
\text { - } & \text { What should I look for? } \\
\text { - } & \text { Team Meeting time (subject to Tech Meeting) } \\
& \text { Final pre comp team meeting (includes } \\
& \text { number distribution \& final instructions) }\end{array}$ & $\begin{array}{ll}\text { - } & \text { Add current heat and final time } \\
\text { - } & \text { Review qualifying } \\
\text { - } & \text { requirements on publication } \\
\text { - When will I know my heats? } & \text { Tactics? }\end{array}$ & $\begin{array}{l}\text { Physio /Massage? } \\
\text { - As normal? } \\
\text { - } \quad \text { Chat is normal for you? } \\
\quad \text { physio }\end{array}$ \\
\hline & $\begin{array}{l}\text { Recovery / Cooling Strategy: } \\
\text { - } \quad \text { At track side } \\
\text { - In Village }\end{array}$ & $\begin{array}{l}\text { Preparing for Day(s) of Competition (bringing it } \\
\text { all together on a repeated basis): } \\
\text { - Walk the routes - check warm up to stadium } \\
\text { times, access, times to toilets, etc. } \\
\text { - Check out the facilities, announcements, etc. }\end{array}$ & $\begin{array}{l}\text { Influences on Warm up Strategy - } \\
\text { TO BE PRACTISED } \\
\text { - Travel time to stadium? } \\
\quad \text { Call room times? }\end{array}$ & $\begin{array}{l}\text { Warm Up: } \\
\text { - } \quad \text { Timing \& content }\end{array}$ \\
\hline & $\begin{array}{l}\text { Environmental: } \\
\text { - } \quad \text { Pollution } \\
\text { - } \quad \text { Sunburn }\end{array}$ & $\begin{array}{l}\text { When to Rehearse? } \\
\text { - Schedule / timing } \\
\text { - When to relax?? }\end{array}$ & $\begin{array}{l}\text { ANY practice? } \\
\text { - } \quad \text { What will be allowed within } \\
\text { stadium? } \\
\text { - How intense to practice? }\end{array}$ & $\begin{array}{l}\text { Massage warm up/down? } \\
-\quad \text { As normal? } \\
\text { - Check run through with } \\
\text { nominated physio/team or } \\
\text { personal coach }\end{array}$ \\
\hline
\end{tabular}

N.B. Cascade communication strategy in case of team emergency procedure 
PHASE 5: Competition Day ${ }^{3}$ (INSERT TIMES, ROUNDS, AND PROGRESSION RULES AS APPROPRIATE)

\begin{tabular}{|c|c|c|c|c|}
\hline & PHYSIOLOGICAL & MENTAL/ORGANIZATIONAL & TECHNICAL/TACTICAL & PHYSICAL/MEDICAL \\
\hline 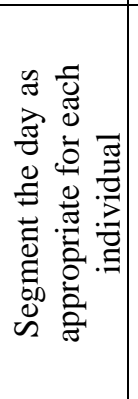 & $\begin{array}{ll} & \text { Hydration Strategy for Competition Day } \\
\text { - } & \text { Nutrition Strategy for Competition Day } \\
& \text { Round timings - intervals and potential for } \\
& \text { refueling/downtime }\end{array}$ & $\begin{array}{ll}\text { - } & \text { Double check access and timings with } \\
\text { Personal/Team Coach } \\
\text { - Follow pre-agreed schedule - ask if } \\
\text { concerned: NO SUCH THING AS A SILLY } \\
\text { QUESTION!! } \\
\text { Deploy warm up preparation routine/use } \\
\text { 'holding techniques' for delay (are you happy } \\
\text { with these?) } \\
\text { Use Press Zone contact to structure post event } \\
\text { interviews } \\
\text { You can play a 'red card' to postpone } \\
\text { interviews }\end{array}$ & $\begin{array}{l}\text { KNOW the progression rules - } \\
\text { what do I need to do in THIS } \\
\text { round } \\
\text { Check race/round plan as YOU } \\
\text { need to } \\
\text { Check coach location if } \\
\text { appropriate to event (previously } \\
\text { set but check anyway!) } \\
\text { Info on possible appeals to Press } \\
\text { Zone contact (info to be radioed } \\
\text { asap) }\end{array}$ & $\begin{array}{ll}\text { - } & \text { Accompanying coach has } \\
\text { physio/medical access, locations } \\
\text { and radio } \\
\text { - Let Press Zone contact know about } \\
\text { Doping Tests - Medic to } \\
\text { accompany } \\
\text { - Post event/round check at warm } \\
\text { up/in rest room }\end{array}$ \\
\hline
\end{tabular}

N.B. LOTS of additional info based on individual plan

\footnotetext{
${ }^{3}$ Needs careful thought for multiple events (i.e. rounds, qualifiers) AND INTERVEENING DAYS AS APPROPRIATE!!
} 
Collins and Cruickshank

\section{References}

Arnold, R., \& Sarkar, M. (2014). Preparing athletes and teams for the Olympic Games: Experiences and lessons learned from the world's best sport psychologists. International Journal of Sport and Exercise Psychology. Advance online publication. doi:http://dx.doi.org/10.1080/1612197X.2014.932827

Bandura, A. (1977). Self-efficacy: Towards a unifying theory of behavioural change. Psychological Review, 84, 191-215. doi:10.1037/0033-295X.84.2.191

Blumenstein, B., \& Lidor, R. (2008). Psychological preparation in the Olympic village: A four-phase approach. International Journal of Sport and Exercise Psychology, 6, 287300. doi:10.1080/1612197X.2008.9671873

Cannon-Bowers, J. A., Salas, E., \& Converse, A. (1990). Cognitive psychology and team training: Shared mental models in complex systems. Human Factors Society Bulletin, $33(12), 1-4$.

Collins, D., \& Collins, J. (2011). Putting them together: Skill packages to optimize team/group performance. In D. Collins, A. Button, \& H. Richards (Eds.), Performance psychology: A practitioner's guide (pp. 361-381). Oxford: Elsevier.

Collins, D., Trower, J., \& Cruickshank, A. (2012). Coaching high performance athletes and the high performance team. In V. De Bosscher \& P. Sotiriadou (Eds.), Managing high performance sport (pp. 205-220). Abingdon, Oxon: Routledge.

Cruickshank, A., Collins, D., \& Minten, S. (2014). Driving and sustaining culture change in Olympic sport performance teams: A first exploration and grounded theory. Journal of Sport \& Exercise Psychology, 36, 107-120. doi:10.1123/jsep.2013-0133

Din, C., \& Paskevich, D. (2013). An integrated research model of Olympic podium performance. International Journal of Sports Science and Coaching, 8, 431-444. doi:10.1260/1747-9541.8.2.431 
Fiske, S. T. (2004). Social beings: A core motives approach to social psychology. Hoboken, NJ: Wiley \& Sons.

Galloway, S. M. (2007). Consulting with Olympic track and field hopefuls: It can't be this easy ...or could it? Athletic Insight: The Online Journal of Sport Psychology, 9, 2936.

Goodhart, P., \& Chataway, C. (1968). War without weapons. London: W.H. Allen.

Gordin, R. D., \& Henschen, K. P. (2012). Reflections on the psychological preparation of the USA ski and snowboard team for the Vancouver 2010 Olympic Games. Journal of Sport Psychology in Action, 3, 88-97. doi:10.1080/21520704.2012.683091

Gould, D., \& Maynard, I. (2009). Psychological preparation for the Olympic Games. Journal of Sports Sciences, 27, 1393-1408. doi:10.1080/02640410903081845

Haberl, P., \& McCann, S. (2012). Evaluating USOC sport psychology consultant effectiveness: A philosophical and practical imperative at the Olympic Games. Journal of Sport Psychology in Action, 3, 65-76. doi:10.1080/21520704.2012.683095

Harberl, P., \& Peterson, K. (2006). Olympic-size ethical dilemmas: Issues and challenges for sport psychology consultants on the road and at the Olympic Games. Ethics \& Behavior, 16, 25-40. doi:10.1207/s15327019eb1601_4

Hermansson, G., \& Hodge, K. (2012). Uncontrollable outcomes: Managing expectations at the Olympics. Journal of Sport Psychology in Action, 3, 127-138. doi:10.1080/21520704.2012.683086.

Hodge, K., \& Hermansson, G. (2007). Psychological preparation of athletes for the Olympic context: The New Zealand summer and winter Olympic teams. Athletic Insight: The Online Journal of Sport Psychology, 9, 1-14.

Kristiansen, E., \& Roberts, G. C. (2010). Young elite athletes and social support: Coping with competitive and organizational stress in "Olympic" competition. Scandinavian 
Collins and Cruickshank

Journal of Medicine and Science in Sports, 20, 686-695. doi:10.1111/j.16000838.2009.00950.x

Kristiansen, E., Hanstad, D. V., \& Roberts, G. C. (2011). Coping with the media at the Vancouver Winter Olympics: "We all make a living out of this". Journal of Applied Sport Psychology, 23, 443-458. doi:10.1080/10413200.2011.598139

Martin, G., \& Pear, J. (2003). Behavior modification: What it is and how to do it $\left(7^{\text {th }}\right.$ ed.). Englewood Cliffs, NJ: Prentice Hall.

Mascarenhas, D., \& Smith, N. C. (2011). Developing the performance brain: Decision making under pressure. In D. Collins, A. Button, \& H. Richards (Eds.), Performance psychology: A practitioner's guide (pp. 245-269). Oxford: Elsevier.

McCann, S. (2008). At the Olympics, everything is a performance issue. International Journal of Sport and Exercise Psychology, 6, 267-276.

doi:10.1080/1612197X.2008.9671871

Olusoga, P., Maynard, I., Hays, K., \& Butt, J. (2012). Coaching under pressure: A study of Olympic coaches. Journal of Sports Sciences, 30, 229-239. doi:02640414.2011.639384

Pathiravithana. R. (2014). Combat appreciation. Retrieved from http:// http://www.scribd.com/rpathiravithana/documents

Pensgaard, A. M., \& Duda, J. L. (2003). Sydney 2000: The interplay between emotions, coping and the performance of Olympic-level athletes. The Sport Psychologist, 17, 253-267.

Pensgaard, A. M. (2008). Consulting under pressure: How to help an athlete deal with unexpected distracters during Olympic Games 2006. International Journal of Sport and Exercise Psychology, 6, 301-307. doi:10.1080/1612197X.2008.9671874 
Portenga, S. T., Aoyagi, M. W., \& Statler, T. A. (2012). Consulting on the run: Performance psychology and the preparation of USA track and field athletes for the Olympics. Journal of Sport Psychology in Action, 3, 98-108. doi:10.1080/21520704.2012.683087

Sabre (2014). The army appreciation process. Retrieved from http:// http://www.sabrehq.com/team_building_articles/army-appreciation-process.htm Samulski, D. M., \& Lopes, M. C. (2008). Counseling Brazilian athletes during the Olympic Games in Athens 2004: Important issues and intervention techniques. International Journal of Sport and Exercise Psychology, 6, 277-286. doi:10.1080/1612197X.2008.9671872

Schinke, R. J., Battochio, R. C., Dubuc, N. G., Swords, S., Apolloni, G., \& Tenenbaum, G. (2008). Understanding the adaptation strategies of Canadian Olympic athletes using archival data. Journal of Clinical Sports Psychology, 2, 337-356.

Sharp, L., Hodge, K., \& Danish, S. (2014). Sport psychology consulting at elite sport competitions. Sport, Exercise, and Performance Psychology, 3(2), 75-88. doi:10.1037/spy0000011

Vernacchia, R. A., \& Henschen, K. P. (2008). The challenge of consulting with track and field athletes at the Olympic Games. International Journal of Sport and Exercise Psychology, 6, 254-266. doi:10.1080/1612197X.2008.9671870

Williams, D. E., \& Andersen, M. B. (2012). Identity, wearing many hats, and boundary blurring: The mindful psychologist on the way to the Olympic and Paralympic Games. Journal of Sport Psychology in Action, 3, 139-152. doi:10.1080/21520704.2012.683090 